\title{
HUBUNGAN TINGKAT PENDIDIKAN DAN PENGETAHUAN IBU DENGAN PENYAPIHAN ASI PADA BALITA USIA 2 TAHUN DI DESA KEDUNGBULUS KECAMATAN GEMBONG KABUPATEN PATI
}

\author{
Sussila Asih" ${ }^{1)}$, Uswatun Kasanah ${ }^{2)}$, Sifa Altika ${ }^{3)}$ \\ ${ }^{1,2)}$ Prodi Sarjana Kebidanan, ${ }^{3)}$ Prodi D-III Kebidanan \\ Stikes Bakti Utama Pati \\ J1. Ki Ageng Selo No. 15 Pati 59114 \\ Emai: sussilaquee@gmail.com
}

\begin{abstract}
ABSTRAK
Menyapih adalah membiasakan anak untuk lepas dari ASI. Di usia tertentu bayi harus dilepas dari susu ibu. Menyapih sebaiknya dilakukan minimal di usia 1 tahun tapi jangan sampai lebih dari 2 tahun. Menyapih terlalu dini memiliki resiko sebab hanya ASI yang terbaik untuk bayi, akibatnya bayi mudah terserang penyakit, antara lain diare (Meggit, 2013). Tujuan penelitian ini yaitu untuk mengetahui hubungan tingkat pendidikan dan pengetahuan ibu dengan penyapihan ASI pada balita usia 2 tahun di Desa Kedungbulus Kecamatan Gembong Kabupaten Pati Tahun 2020. Jenis penelitian yang digunakan dalam penelitian ini adalah analitik korelasional dengan rancangan cross sectional. Berdasarkan teknik total sampling diperoleh jumlah sampel sebanyak 40 responden. Hasil penelitian menunjukkan; 1). Sebagian besar pendidikan menengah 30 responden $(75 \%)$, 2). Sebagian besar pengetahuan cukup 31 responden (77,5\%), 3).sebagian besar balita usia 2 tahun sudah disapih 29 responden $(72,5 \%), 4)$.ada hubungan antara variabel pendidikan ibu dengan penyapihan ASI pada balita usia 2 tahun dengan nilai signifikan $0,027<0,05,5$ ). ada hubungan antara variabel pengetahuan ibu dengan penyapihan ASI pada balita usia 2 tahun dengan nilai signifikan $0,003<0,05$. Tenaga kesehatan diharapkan dapat meningkatkan pelayanan KIA dan menggalakkan program peningkatan pemberian ASI.
\end{abstract}

Kata kunci : Penyapihan, Balita, Pendidikan dan Pengetahuan

\begin{abstract}
Weaning is to accustom the child to release ASI. At a certianage the baby must be released from mother's milk. Weaning should be done at least 1 year of age but not more than 2 years. Weaning too early has a risk because only the best breast milk for babies, as a result the baby is susceptible to desease, indcuding diarrhea (Meggit, 2013). The purpose of this study was to determine the relationship between education level and mother's knowledge and breasfeeding weaning for toddlers aged 2 years in Kedungbulus Village, Gembong Distric, Pati Regency. This type of research used in this study is a correlational analytic crosssectional design. Based on the total sampling technique the number of samples was 40 respondents. The results showed; 1) Most of secondary education 30 responden (975\%), 2). most of the enough knowledge 31 respondents (77,5\%), 3). most of the toddlers aged 2 years have been weaned 29 respondents $(72,5 \%)$, 4). there is a relationship between maternal education variables with breastfeeding weaningin toddlers aged 2 years with a significant value of $(0,0270,001<0,05,5)$. there is a relationship between mother's knowledge variables with weaning milk in toddler aged 2 years with a significant value of 0,003<0,05. Healt workersare expected to be able to improve KIA services and promote a program to increase breasitfeeding.
\end{abstract}

Keywords: Weaning, toddlers, Education and Knowledge 


\section{PENDAHULUAN}

Di indonesia terutama di kota-kota besar terlihat adanya tendensi penurunan pemberian ASI. Di negara berkembang atau pedesaan terjadi karena adanya kecenderungan dari masyarakat untuk meniru sesuatu yang dianggapnya modern yang datang dari negara yang telah maju atau yang datang dari kota besar (Soetjiningsih, 2012).

Bagi bayi ASI merupakan makanan yang paling sempurna, di mana kandungan gizi sesuai kebutuhan untuk pertumbuhan dan perkembangan yang optimal. ASI memberi energi dan nutrien penting, bahkan sampai anak berusia dua tahun (Rosida, 2016).

ASI juga mengandung 200 unsur-unsur pokok, antara lain zat putih telur, lemak, karbohidrat, vitamin, mineral, faktor pertumbuhan, hormon, enzim, zat kekebalan dan sel darah putih. Semua zat ini terdapat secara proposional dan seimbang satu dengan yang lainnya. (Roesli, 2013)

ASI memberikan zat kekebalan yang belum dapat dibuat oleh bayi. Dengan adanya zat anti infeksi dari ASI maka bayi akan terlindung dari berbagai macam infeksi. ASI juga mengandung imunoglobulin, suatu protein yang baredar dan bertugas memerangi infeksi yang masuk dalam tubuh bayi (Roesli, 2013).

Menyapih adalah membiasakan anak untuk lepas dari ASI. Di usia tertentu bayi harus dilepas dari susu ibu. Menyapih sebaiknya dilakukan minimal di usia 1 tahun tapi jangan sampai lebih dari 2 tahun. Semakin bertambah usia, kualitas ASI juga sudah tidak vital lagi karena anak lebih membutuhkan makanan bergizi (Singgih \& Advani, 2006).

Menyapih terlalu dini memiliki resiko sebab hanya ASI yang terbaik untuk bayi, ASI mengandung zat antibodi untuk tubuh bayi. Jika bayi kurang mendapatkan ASI dan ibu menggantinya dengan susu formula, maka zat antibodinya akan berkurang. Akibatnya bayi mudah terserang penyakit, antara lain diare (Meggit, 2013).

Survey awal yang di lakukan oleh peneliti melalui wawancara pada $10 \mathrm{ibu}$ yang mempunyai balita yang sudah disapih didesa Kedungbulus kecamatan Gembong Kabupaten
Pati didapatkan hasil bahwa dari 10 ibu menyusui yang sudah disapih tersebut $30 \%$ yang disapih pada usia 2 tahun. Hal ini dikarenakan ibu sudah mengetahui batas penyapihan yaitu 2 tahun dan anak sudah mengenal makanan padat yang mengandung gizi lebih banyak. $70 \%$ yang disapih pada usia lebih dari 2 tahun. Hal ini disebabkan karena keterbatasan pengetahuan yang dimiliki dan pekerjaan ibu sebagai ibu rumah tangga sehingga banyak waktu yang tersedia untuk menyusui bayinya. Serta faktor lain yang mempengaruhi pemberian ASI diantaranya faktor sosial ekonomi yang tidak mendukung dalam memberikan susu formula.

Dari data di atas, penulis tertarik untuk melakukan penelitian tentang "Hubungan Tingkat Pendidikan dan Pengetahuan Ibu Dengan Penyapihan ASI Pada Balita Usia 2 Tahun di desa Kedungbulus Kecamatan Gembong Kabupaten Pati Tahun 2020”.

Tujuan umum penelitian ini adalah untuk mengetahui hubungan tingkat pendidikan dan pengetahuan ibu dengan penyapihan ASI pada balita usia 2 tahun di Desa Kedungbulus Kecamatan Gembong Kabupaten Pati Tahun 2020. Adapun tujuan khususnya adalah untuk mendeskripsikan pendidikan ibu yang melakukan penyapihan ASI pada balita usia 2 tahun, untuk mendeskripsikan pengetahuan ibu yang melakukan penyapihan ASI pada balita usia 2 tahun, untuk mendeskripsikan penyapihan ASI pada balita usia 2 tahun, untuk menganalisis hubungan tingkat pendidikan ibu dengan penyapihan ASI pada balita usia 2 tahun, untuk menganalisis hubungan tingkat pengetahuan ibu dengan penyapihan ASI pada balita usia 2 tahun. Jenis penelitian yang digunakan adalah penelitian analitik dengan metode pendekatan cross sectional.

\section{METODE}

Jenis penelitian yang digunakan dalam penelitian ini adalah analitik. Metode penelitian yang digunakan dalam penelitian ini adalah survei dengan pendekatan cross sectional. Ruang lingkup penelitian ini termasuk dalam lingkup ilmu kebidanan dan ilmu kesehatan anak. Variabel independen adalah tingkat 
pendidikan dan tingkat pengetahuan ibu, penyapihan berjumlah 1 pertanyaan. sedangkan variabel dependen adalah Pengolahan data dilakukan dengan cara editing, penyapihan ASI pada balita usia 2 tahun. coding, scoring dan tabulasi data. Sedangkan Populasi dan sampel dalam penelitian adalah semua ibu balita usia 2 tahun sebanyak 40 ibu balita yang diambil dengan teknik total sampling. Instrumen yang digunakan Pertanyaan mengenai tingkat pendidikan berjumlah 1 pertanyaan. Pernyataan pengetahuan tentang penyapihan berjumlah 10 pernyataan. Pertanyaan mengenai usia analisis data meliputi uji univariat dan bivariat dengan Chi Square.

\section{HASIL}

\section{Analisis Univariat}

a. Tingkat Pendidikan

Tabel.4.1

Distribusi Frekuensi Responden Berdasarkan Tingkat Pendidikan di Desa Kedungbulus Kecamatan Gembong Kabupaten Pati Tahun $2020(n=40)$

\begin{tabular}{lcc}
\hline \multicolumn{1}{c}{ Kategori } & Frekuensi & Persentase (\%) \\
\hline Dasar & 8 & 20.0 \\
Menengah & 30 & 75.0 \\
Tinggi & 2 & 5.0 \\
\hline Total & 40 & 100,0 \\
\hline
\end{tabular}

Tabel 4.1 menunjukkan bahwa tingkat pendidikan sebagian besar masuk dalam kategori pendidikan menengah sebanyak 30 responden $(75 \%)$, pendidikan dasar sebanyak 8 responden $(20 \%)$, dan pendidikan tinggi sebanyak 2 responden $(5 \%)$.

b. Pengetahuan

c.

Tabel.4.2 Distribusi Frekuensi Responden Berdasarkan Pengetahuan Ibu di Desa Kedungbulus Kecamatan Gembong Kabupaten Pati Tahun 2020 ( $n=40)$

\begin{tabular}{lccc}
\hline & Kategori & Frekuensi & Persentase (\%) \\
\hline Baik & 3 & 7,5 \\
Cukup & 31 & 77,5 \\
Kurang & 6 & 15,0 \\
\hline Total & 0 & 100,0 \\
\hline
\end{tabular}

Tabel 4.2 menunjukkan bahwa tingkat pengetahuan sebagian besar masuk dalam kategori pengetahuan cukup sebanyak 31 responden (77,5\%), pengetahuan baik sebanyak 3 responden $(7,5 \%)$, dan pengetahuan kurang sebanyak 6 responden $(15 \%)$.

d. Penyapihan ASI pada Balita Usia 2 Tahun

Tabel.4.3 Distribusi Frekuensi Responden Berdasarkan Penyapihan ASI pada Balita Usia 2 Tahun di Desa Kedungbulus Kecamatan Gembong Kabupaten Pati Tahun 2020 (n=40)

\begin{tabular}{lcc}
\hline \multicolumn{1}{c}{ Kategori } & Frekuensi & Persentase (\%) \\
\hline Disapih & 29 & 72.5 \\
Belum disapih & 11 & 27.5 \\
\hline Total & 40 & 100,0 \\
erdasarkan tabel 4.3 diketahui bahwa & \multicolumn{2}{c}{$\begin{array}{l}(72,5 \%) \\
\text { sebanyak 11 responden }(27,5 \%) .\end{array}$}
\end{tabular}

sudah disapih sebanyak 29 responden

\section{Analisis Bivariat}


a. Hubungan Antara Tingkat Pendidikan

Usia 2 tahun.

Dengan Penyapihan ASI Pada Balita

Tabel.4.4 Tabulasi Silang antara Tingkat Pendidikan dengan Penyapihan ASI pada

Balita Usia 2 Tahun di Desa Kedungbulus Kabupaten Pati Tahun $2020(n=40)$

\begin{tabular}{|c|c|c|c|}
\hline & $\begin{array}{c}\text { Penyapihan ASI Pada } \\
\text { Balita Usia } 2 \text { Tahun }\end{array}$ & \multirow{2}{*}{ Total } & \multirow{2}{*}{$\mathbf{P}_{\text {Value }}$} \\
\hline Tingkat Pendidikan & $\begin{array}{cc}\text { Disapih } & \text { Belum } \\
\text { Disapih }\end{array}$ & & \\
\hline
\end{tabular}

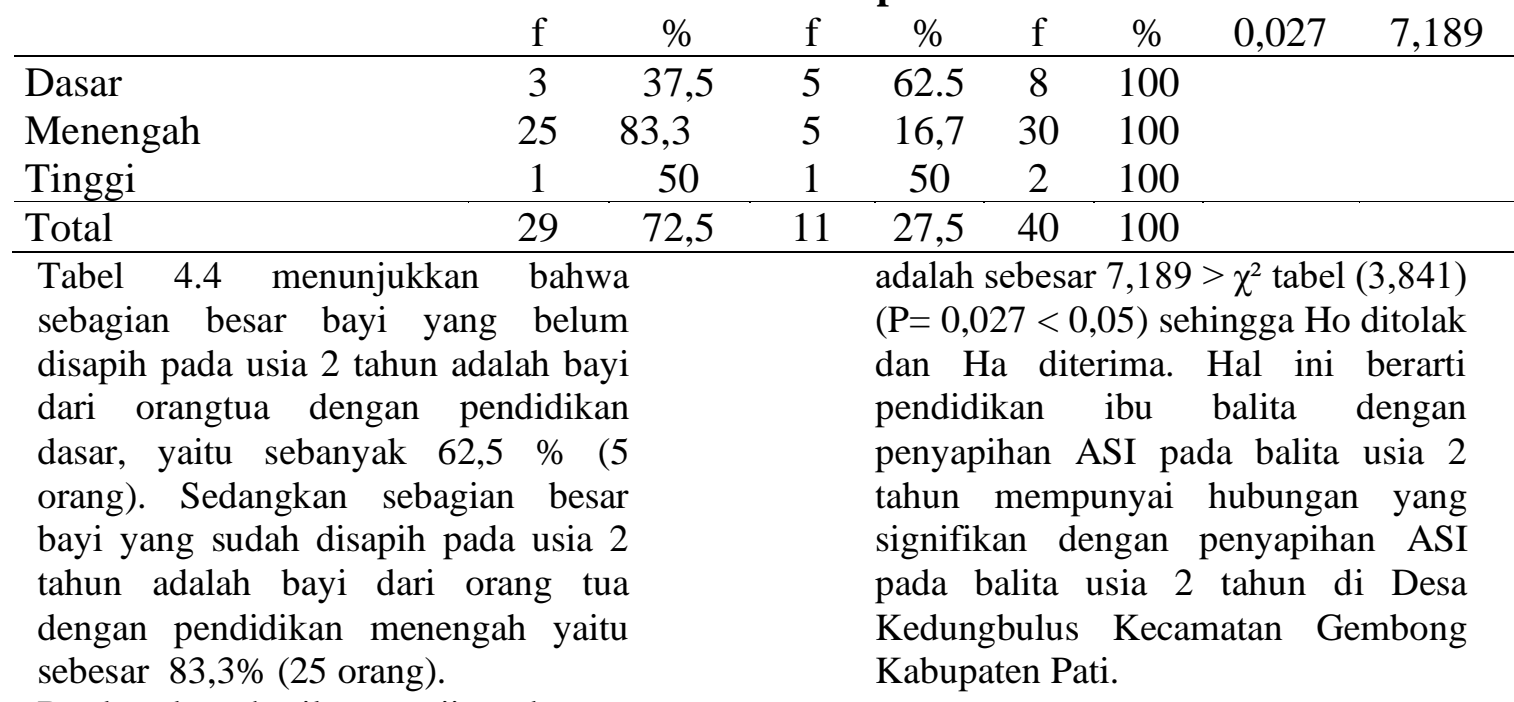

Berdasarkan hasil pengujian dengan menggunakan alat analisis chi square dapat diketahui bahwa nilai $\chi^{2}$ hitung b. Hubungan antara Tingkat

Pengetahuan dengan Penyapihan

ASI pada Balita Usia 2 Tahun.

Tabel.4.5

Tabulasi Silang antara Tingkat Pengetahuan dengan Penyapihan ASI pada Balita Usia 2 Tahun di Desa Kedungbulus Kecamatan Gembong Kabupaten Pati Tahun $2020(n=40)$

\begin{tabular}{lcccccccc}
\hline & \multicolumn{9}{c}{ Penyapihan ASI Pada } & & & & \\
\multicolumn{1}{c}{ Balita Usia 2 Tahun } & & Total & $\mathrm{P}_{\text {value }}$ & $\chi^{2}$ \\
& \multicolumn{7}{c}{ Disapih } & \multicolumn{2}{c}{ Belum } & & & & \\
& Disapih & & & & \\
& $\mathrm{f}$ & $\%$ & $\mathrm{f}$ & $\%$ & $\mathrm{f}$ & $\%$ & 0,003 & 11,443 \\
\hline Baik & 2 & 66,7 & 1 & 33,3 & 3 & 100 & & \\
Cukup & 26 & 83,9 & 5 & 16,1 & 31 & 100 & & \\
Kurang & 1 & 16,7 & 5 & 83,3 & 6 & 100 & & \\
\hline Total & 29 & 72,5 & 11 & 27,5 & 40 & 100 & & \\
\hline
\end{tabular}


Pada Tabel 4.5 menunjukkan bahwa sebagian besar bayi yang belum disapih pada usia 2 tahun adalah bayi dari orangtua dengan pengetahuan kurang, yaitu sebanyak 83,3 \% (5 orang). Sedangkan sebagian besar bayi yang sudah disapih pada usia 2 tahun adalah bayi dari orang tua dengan pengetahun cukup yaitu sebesar 83,9\% (26 orang).

Berdasarkan hasil pengujian dengan menggunakan alat analisis chi square dapat diketahui bahwa inlai $\chi^{2}$ hitung adalah sebesar $11,443>\chi^{2}$ tabel $(3,841)(\mathrm{P}=0,003<0,05)$ sehi ngga

Ho ditolak dan Ha diterima. Hal ini berarti pengetahuan ibu balita dengan penyapihan ASI pada balita usia 2 tahun mempunyai hubungan yang signifikan dengan penyapihan ASI pada balita usia 2 tahun didesa Kedungbulus kecamatan Gembong Kabupaten Pati Tahun 2020.

\section{PEMBAHASAN}

\section{a. Tingkat Pendidikan Ibu}

Berdasarkan teori Notoatmodjo (2013), pendidikan merupakan segala upaya yang direncanakan untuk mempengarui orang lain baik individu, kelompok atau masyarakat sehingga mereka melakukan apa yang diharapkan oleh pelaku pendidikan.

Dalam Ahmadi \& Uhbiyanti (2014), tujuan pendidikan nasional yaitu membangun kualitas manusia yang taqwa terhadap Tuhan Yang Maha Esa dan selalu dapat meningkatkan hubungan dengan-Nya, sebagai warga Negara yang ber-pancasila mempunyai semangat dan kesadaran yang tinggi, berbudi pekerti yang luhur dan berkepribadian yang kuat; demokrasi, dapat memelihara hubungan antara sesama manusia dan dengan lingkungan; sehat jasmani, maupun mengembangkan daya estetik kesanggupan membangun diri dan masyarakat.

Mengacu pada teori tersebut kemudian dilakukan penelitian untuk mengetahui keterkaitan antara teori dan praktek. Hasil dari penelitian yang dilakukan terhadap 40 responden menunjukkan bahwa tingkat pendidikan tinggi ada 2 responden (12,5\%), tingkat pendidikan menengah ada 30 responden $(75,0 \%)$, tingkat pendidikan dasar ada 8 responden $(20,0 \%)$.

Sebagian besar ibu yang mempunyai balita sudah disapih memiliki pendidikan menengah karena mereka mendapatkan pelajaran, informasi tentang batas penyapihan lebih banyak. Beberapa ibu yang mempunyai balita sudah disapih memiliki pendidikan tinggi karena faktor yang mempengaruhi pengetahuan salah satunya adalah pendidikan, semakin tinggi pendidikannya semakin luas pengetahuannya dan mampu menerima informasi sesuai dengan perkembangan zaman. Sedangkan beberapa ibu yang mempunyai balita sudah disapih memiliki pendidikan rendah karena sosial ekonomi yang kurang sehingga tidak dapat melanjutkan ke pendidikan yang lebih tinggi.

b. Tingkat Pengetahuan Ibu

Berdasarkan teori Notoatmodjo (2013), pengetahuan merupakan hasil dari tahu dan ini terjadi setelah orang melakukan penginderaan terhadap objek tertentu. Penginderaan terjadi melalui panca indra manusia, yakni: indra penglihatan, pendengaran, penciuman, rasa dan raba. Sebagian besar pengetahuan manusia diperoleh melalui mata dan telinga.

Pengetahuan atau kognitif merupakan domain yang sangat penting untuk terbentuknya tindakan seseorang (Overt Behavior). Pengetahuan yang dicakup didalam domain kognitif mempunyai 6 tingkat yakni: tahu, Memahami, Aplikasi, Analisis, Sintesis, Evaluasi. Pengetahuan dapat membentuk suatu sikap dan menimbulkan suatu perilaku di dalam kehidupan sehari-hari.

Mengacu pada teori tersebut kemudian dilakukan penelitian untuk mengetahui keterkaitan antara teori dan praktek. Hasil dari penelitian yang dilakukan terhadap 40 responden menunjukkan bahwa tingkat pengetahuan baik ada 3 responden $(7,5 \%)$, tingkat pengetahuan cukup ada 31 responden (77,5\%), tingkat pengetahuan kurang ada 6 responden $(15,0 \%)$. 
Sebagian besar ibu yang mempunyai balita sudah disapih memiliki pengetahuan yang cukup tentang penyapihan karena mereka mendapatkan informasi tentang penyapihan dari Bidan, media elektronik dan media cetak. Ibuibu juga aktif dalam kegiatan posyandu, pengajian, PKK dan yasinan RT sehingga mereka bisa saling berbagi pengalaman dan pengetahuan. Beberapa ibu yang mempunyai balita sudah disapih memilki pengetahuan baik karena faktor yang mempengaruhi pengetahuan salah satunya ada pendidikan, sebab semakin tinggi pendidikan seseorang akan mempermudah dalam menerima informasi yang ada. Sedangkan beberapa ibu yang mempunyai balita sudah disapih memiliki pengetahuan kurang karena mereka memiliki pendidikan dasar dan kurang mendapatkan informasi dari mdia cetak maupun elektronik, bidan desa dan mereka juga jarang mengikuti kegiatan posyandu.

c. Penyapihan ASI pada Balita Usia 2 Tahun

Berdasarkan hasill penelitian menunjukkan bahwa penyapihan ASI pada balita usia 2 tahun sebagian besar yang disapih sebanyak 29 responden $(72,5 \%)$ dan sebagian kecil yang belum disapih sebanyak 11 responden $(27,5 \%)$. Sehingga didapat proporsi terbanyak penyapihan ASI pada balita usia 2 tahun yang disapih adalah sebanyak 29 responden $(72,5 \%)$.

Penyapihan adalah suatu perubahan prosesif pemberian makanan pada bayi dari yang semula hanya mendapat ASI sebagai satu-satunya sumber makanan menuju pada suatu jenis makanan seharihari keluarga (Suradi, 2012)

Menyapih adalah suatu proses berhentinya masa menyusui secara berangsur-angsur atau sekaligus (Soraya, 2011)

Berdasarkan dari hasil penelitian diatas diketahui bahwa sebagian besar balita usia 2 tahun sudah disapih, hal ini dapat diketahui bahwa ibu melakukan penyapihan dengan alasan anak yang disapih pada usia 1-2 tahun kebutuhan gizinya terpenuhi dan selera makannya akan baik serta setelah anak dilakukan penyapihan anak akan lebih mandiri.

Hasil penelitian ini sejalan dengan penelitian yang dilakukan oleh Umamah, (2015) tetang "hubungan antara penyapihan dengan berat badan di wilayah Rw 03 Kedurus Kecamatan Karangpilang Surabaya" dengan hasil penelitian ada hubungan antara penyapihan dengan berat badan di wilayah Rw 03 Kedurus Kecamatan Karangpilang Surabaya, ditandai dengan $\mathrm{p}$ value $=0,000$.

d. Hubungan antara Tingkat Pengetahuan Ibu dengan Penyapihan ASI pada Balita Usia 2 Tahun

Berdasarkan hasil pengujian dengan menggunakan alat analisis chi square dapat diketahui bahwa nilai $\chi^{2}$ hitung adalah sebesar 7,189> $\chi^{2}$ tabel $(3,841)(\mathrm{P}=0,027<0,05)$ sehingga Ho ditolak dan Ha diterima. Hal ini berarti pendidikan ibu balita dengan penyapihan ASI pada balita usia 2 tahun mempunyai hubungan yang signifikan dengan penyapihan ASI pada balita usia 2 tahun didesa Kedungbulus kecamatan Gembong Kabupaten Pati Tahun 2020.

Sebagian besar bayi yang belum disapih pada usia 2 tahun adalah bayi dari orangtua dengan pendidikan dasar, yaitu sebanyak $62,5 \%$ (5 orang). Sedangkan sebagian besar bayi yang sudah disapih pada usia 2 tahun adalah bayi dari orang tua dengan pendidikan menengah yaitu sebesar $83,3 \%$ (25 orang).

Berdasarkan jumlah tabulasi diatas dapat diketahui kecenderungan pendidikan ibu balita dengan penyapihan ASI pada balita usia 2 tahun menengah sebanyak 30 responden $(75,0 \%)$ dengan penyapihan ASI pada balita usia 2 tahun yang disapih yaitu sebanyak 29 responden $(72,5 \%)$.

Pendidikan atau paedagogie berasal dari bahasa yunani, terdiri dari kata "PAIS", artinya anak, dan "AGAIN" diterjemahkan membimbing, jadi paedagogie yaitu bimbingan yang diberikan kepada anak (Ahmadi \& Uhbiyati, 2007). Secara umum pendidikan diartikan sebagai segala upaya yang direncanakan untuk mempengaruhi 
orang lain baik individu, kelompok atau masyarakat sehingga mereka melakukan apa yang diharapkan oleh pelaku pendidikan (Notoatmodjo, 2013).

Keputusan penyapihan yang dilakukan ibu biasanya dipengaruhi oleh beberapa faktor yaitu anak sudah siap disapih, konsumsi makan dan susu sudah banyak, ASI yang tidak deras lagi, kondisi ibu yang bekerja dan kondisi ibu yang tidak memungkinkan memberikan ASI (Arini, 2012).

Hasil penelitian diketahui bahwa sebagian besar responden mempunyai tingkat pendidikan yang menengah sehingga responden mudah mendapatkan informasi yang berkaitan dengan pentingnya melakukan penyapihan pada balita usia 2 tahun..

Hasil penelitian ini sejalan dengan penelitian yang dilakukan oleh Hani Septiani, dkk (2019) dengan judul penelitian "Hubungan Tingkat Pendidikan Ibu Menyusui Dengan Usia Penyapihan Dalam Pemberian ASI Pada Bayi Di Bawah Usia 1 Tahun Di Wilayah Kerja Puskesmas Panumbangan", hasil uji statistik menunjukkan ada hubungan yang signifikan antara tingkat pendidikan ibu menyusui dengan usia penyapihan dalam pemberian ASI di wilayah kerja Puskesmas Panumbangan Kabupaten Ciamis tahun 2012 ( $\mathrm{p}$ value $=0,000$ ).

Dari hasil penelitian tersebut diatas dapat ditarik kesimpulan bahwa orang tua dengan tingkat pendidikan yang tinggi akan melakukan penyapihan pada anaknya pada usia 2 tahun sesuai dengan informasi yang didapatkan dari tenaga kesehatan, hal ini disebabkan karena seseorang dengan pendidikan tinggi pendidikan ibu yang akan berpengaruh terhadap tingkat kedewasaan dan kematangan dalam berfikir dan bertindak, sehingga ibu mudah terpengaruh dengan informasi baik yang didapat dari petugas kesehatan, ataupun media cetak dan elektronik tentang manfaat ASI bagi bayinya dan bersedia untuk melakukan sesuai dengan informasi yang diperolehnya secara baik.

\section{e. Hubungan antara Tingkat} Pengetahuan Ibu dengan Penyapihan ASI pada Balita Usia 2 Tahun

Berdasarkan hasil pengujian dengan menggunakan alat analisis chi square dapat diketahui bahwa nilai $\chi^{2}$ hitung adalah sebesar $11,037>\chi^{2}$ tabel $(3,841) \quad(\mathrm{P}=0,001<0,05)$ sehingga Ho ditolak dan Ha diterima. Hal ini berarti pengetahuan ibu balita dengan penyapihan ASI pada balita usia 2 tahun mempunyai hubungan yang signifikan dengan penyapihan ASI pada balita usia 2 tahun didesa Kedungbulus kecamatan Gembong Kabupaten Pati Tahun 2020.

Pengetahuan ibu balita dengan penyapihan ASI pada balita usia 2 tahun baik menunjukkan angka yang paling dominan yaitu sebanyak 3 responden (7,5\%), pengetahuan ibu balita dengan penyapihan ASI pada balita usia 2 tahun cukup menunjukkan angka sebanyak 31 responden $(77,5 \%)$. pengetahuan ibu balita dengan penyapihan ASI pada balita usia 2 tahun kurang menunjukkan angka sebanyak 6 responden $(15,0 \%)$.

Berdasarkan jumlah tabulasi diatas dapat diketahui kecenderungan pengetahuan ibu balita dengan penyapihan ASI pada balita usia 2 tahun cukup sebanyak 31 responden $(77,5 \%)$ dengan penyapihan ASI pada balita usia 2 tahun yang disapih yaitu sebanyak 29 responden $(72,5 \%)$.

Seseorang yang memiliki tingkat pengetahuan yang baik akan mempengaruhi status kesehatannya. Tingkat pengetahuan yang baik juga berhubungan dengan faktor ekonomi dan pendidikan yang baik pula. Hal ini berkaitan dengan tingkat pengetahuannya yang baik sehingga mampu menerapkan penyapihan pada anaknya. Selain itu perilaku orang tua dalam menerapkan penyapihan pada balita dapat mempengaruhi keberhasilan penyapihan sehingga dapat mempengaruhi tingkat kepercayaan diri balita (Notoatmodjo, 2013).

Dengan pengetahuan seseorang cenderung akan hati-hati dan bersikap profesional dalam mengambil segala tindakan, baik untuk dirinya sendiri atau 
orang lain bahkan terhadap lingkungan juga.

Hasil penelitian ini sejalan dengan penelitian yang dilakukan oleh Esti Nugraheny, (2016) dengan judul penelitian "Faktor-Faktor Yang Berhubungan Dengan Waktu Penyapihan Pada Anak Di Bawah Dua Tahun" Hasil penelitian menunjukkan bahwa ada pengaruh pengetahuan dengan waktu penyapihan pada Anak Bawah Dua Tahun di Dusun Gumulan, Desa Caturharjo, Kecamatan Pandak, Kabupaten Bantul, D.I.Yogyakarta, dengan nilai signifikansi pada hasil menunjukkan $p=0,000<0,05)$.

Berdasarkan uraian tersebut diatas dapat ditarik kesimpulkan bahwa pada seorang ibu yang mempunyai pengetahuan cukup baik dalam menerapkan ASI untuk anaknya, dimungkinkan akan mempengaruhi waktu penyapihan pada anaknya. Pengetahuan seorang ibu tentang ASI dan waktu yang tepat untuk menyapih anaknya akan berpengaruh pada perilaku dalam penyapihan nantinya

\section{SIMPULAN DAN SARAN}

Hasil penelitian menunjukkan hasil bahwa Sebagian besar responden memiliki pendidikan menengah sebanyak 30 responden $(75 \%)$. Sebagian besar responden memiliki pengetahuan cukup sebanyak 31 responden (77,5\%). Sebagian besar repsonden balita usia 2 tahun sudah disapih sebanyak 29 responden $(72,5 \%)$ serta adanya hubungan yang signifikan antara pendidikan ibu dengan penyapihan ASI pada balita usia 2 tahun didesa Kedungbulus kecamatan Gembong Kabupaten Pati dan adanya hubungan yang signifikan antara pengetahuan ibu dengan penyapihan ASI pada balita usia 2 tahun di desa Kedungbulus Kabupaten Pati. penting untuk memberikan pengetahuan khusus bagi para ibu-ibu yang masih mempunyai bayi maupun balita untuk memberikan ASI sampai batas usia penyapihan

\section{DAFTAR PUSTAKA}

Ahmadi, A \& Uhbiyati, N. (2014). Ilmu Pendidikan, Jakarta: Rineka Cipta.

Arikunto, A. (2013). Proses Penelitian Suatu Pendekatan Praktek Edisi Revisi V. Jakarta: EGC.

Arisman, MB. (2014). Gizi Dalam Daur Kehidupan, Jakarta: ECG

Carolyne, Meggit. 2013. Memahami Perkembangan Anak. Jakarta: Indeks.

Nugraheny, Esti dan Amalia, Rizka Putri. (2016). Faktor-Faktor Yang Berhubungan Dengan Waktu Penyapihan Pada Anak Di Bawah Dua Tahun. Jurnal Ilmu Kebidanan, Jilid 3, Nomor 2, hlm 79-85. url: http://jurnal.akbiduk.ac.id/assets/doc/1 70710020153-79-85-

Jurnal\%20Ilmu\%20Kebidanan\%20Jun i\%202017\%20Jilid\%203\%20Nomor\% 202\%20Revisi\%202.pdf Diakses pada tanggal 21 Juni 2020.

Eisenberg, A. (2004). Anak di bawah Tiga Tahun. Apa yang Anda Hadapi Bulan per Bulan, Jakarta: Arcan.

Septiani Hani, dkk (2019). Hubungan Tingkat Pendidikan Ibu Menyusui Dengan Usia Penyapihan Dalam Pemberian ASI Pada Bayi Di Bawah Usia 1 Tahun Di Wialayah Kerja Puskesmas Panumbangan. Tugas Akhir. Program Studi DIII Kebidanan, Fakultas Ilmu Kesehatan, Universitas Galuh. url: http://dx.doi.org/10.25157/midwifery. v1i2.3031. Diakses pada tanggal 21 Juni 2020.

Krinatuti, D. (2008). Menu Sehat Untuk Ibu Hamil dan Menyusui, Jakarta: Puspaswara.

Manuaba, I.B.G. (2015). Ilmu Kebidanan Penyakit Kandungan dan Keluarga Berencana untuk Pendidikan Bidan, Jakarta: ECG. 
Notoatmodjo, S. (2013). Pendidikan dan Perilaku Kesehatan, Jakarta: Rineka Cipta.

Notoatmodjo, S. (2013). Metodologi Penelitian Kesehatan, Jakarta: Rineka Cipta.

Notoatmodjo, S. (2013). Pendidikan dan Perilaku Kesehatan, Jakarta: Rineka Cipta.

Nursalam. (2015). Konsep dan Penerapan Metodologi Penelitian Ilmu Keperawatan, Jakarta: Salemba Medika.

Roesli, U. (2013). Mengenal ASI Ekslusif, Jakarta: Trubus Agri Widya.

Singgih, Y \& Advani, N. (2006). Menyapih Usia 1 tahun, Available at: http://www.tabloid.nakita.com/artikel.ph p3 (2 November 2019).

Soetjiningsih. (2012). ASI Petunjuk Untuk Tenaga Kesehatan, Jakarta: ECG.

Soraya, L. (2011). Menyapih dengan Cinta, Available at: http://asuh.wikia.com/wiki.menyapih (11 November 2019).

Sugiyono. (2016). Statistika Untuk Penelitian. Bandung: Alfabetha

Suradi, R. (2012). Manajemen Laktasi. Jakarta; Perinasia

Supariasa. I.N.2016. Penilaian Status Gizi, Jakarta : ECG 